The Dhaka University Journal of Linguistics: Vol. 1 No. 2 August, 2008 Page : 147-156, Published on August 2009 C Registrar, Dhaka University ISSN-2075-3098

\section{A Cognitive Psychological Explanation of Difficulties in Learning Katakana}

\author{
Muhammad Salim Hossain ${ }^{1}$ \\ Muhammad Kamal Uddin ${ }^{2}$
}

1. Lecturer, School of Business, United international University

2. Associate Professor, Department of Psychology, University of Dhaka

\begin{abstract}
Japanese is one of the difficult languages for the nonnatives. Every year many Bangladeshi students enrolled in language schools to learn Japanese. However, many of them eventually fail to continue the course owing to the difficulties in learning Japanese. The present paper investigated which script of Japanese seems difficult for the learners. The findings indicated that Katakana seems to be difficult for the learners than the Hiragana. Two cognitive psychological explanations of the difficulties associated with in learning Japanese specially Katakana is offered and concludes by suggesting ways to reduce drops-out.
\end{abstract}

Key words: Distinctive features, Hiragana, Katakana, Serial position effect

\section{Introduction}

Compared to many South Asian and European languages, basic Japanese grammar is relatively simple. Complicating factors such as gender, articles and distinctions between plural and singular are missing almost completely in Japanese. Conjugation rules for verbs and adjectives are simple and almost free of exceptions. Nouns are not declinated at all, but appear always in the same form. These facts make the language relatively easy for the beginners.

However, Japanese is perceived to be a difficult language for nonnatives including Bangladeshi for many reasons. One of the aspects of difficulties of the Japanese language is its complex writing system. Unless one is familiar with Chinese characters (kanji), many years of study are necessary to achieve complete literacy. Another aspect of difficulty of any language including Japanese lies in the fact that a person's speech can vary depending on the situation and on the person, one is talking to. A student of the Japanese language has to get familiar with Japanese society and customs in order to understand the detailed rules of the different levels of speech.

There are three sets of scripts in Japanese language. These are (1) Kanji, (2) Hiragana, and (3) Katakana. Kanji made up of the Chinese characters, was first introduced to Japan in the 5th century via Korea. Kanji are ideograms, i.e. each character has its own meaning and corresponds to a word. By combining characters, more words can be created. For example, the combination of "electricity" with "car" means "train". There are several ten thousands of characters.

Before the introduction of Chinese characters, no Japanese writing system existed. Kanji are used for writing nouns, adjectives, adverbs and verbs. But unlike the Chinese language, Japanese cannot be written entirely in kanji. For grammatical endings and words without corresponding kanji, two additional scripts, Hiragana and Katakana, are used.

Around the 9th century, the Japanese developed their own writing system based on syllables: Hiragana and Katakana (together Kana). Of the two kana systems, Hiragana is the more cursive while Katakana is the more angular. Hiragana and Katakana each consists of 46 signs which originally were kanji but were strongly simplified over the centuries. Among these letters 5 are vowels (a i u e o). The rest are syllables combined by one of these vowels with a consonant (ka ki ku ke ko ra ri ru re ro...). In addition, many syllables can be softened or hardened by adding two small strokes or a small circle in the top right corner next to the character. 
Even though one can theoretically write the whole language in Hiragana, it is usually used only for grammatical endings of verbs, nouns, and adjectives, as well as for particles, and several other original Japanese words which are not written in Kanji. Katakana is mainly used for writing loan words and the names of persons and geographical places that can't be written in kanji. Hiragana is the first of all the writing systems taught to Japanese children and to novice learners. Many books for novice are, therefore, written in Hiragana only.

In Bangladesh, one of the major institutions offering Japanese language courses is the Institute of Modern Languages (IML) at the University of Dhaka. The students enrolled here in junior certificate course are taught only Hiragana and Katakana. Hence the concern of the present paper is focused on learning Hiragana and Katakana. Kanji is excluded from the discussion in this paper.

In learning Japanese it is a primary challenge for learners to correctly identify the basic letters. Correct identification of letters influences later performance of learners. Once the basic letters are wellcaptured, the modified and combined letters are easy to grasp because they (modified and combined letters) are just the extensions of basic letters to produce more syllables. Modified letters are extended by using two additional symbols, that is, maru $(\circ)$ and ten ten ("). On the other hand, combined letters are created by using a combination between consonant of $i$ column (consonant $+\mathrm{i}$, for example, $\mathrm{k}+\mathrm{i}=\mathrm{ki}$ ) and semi vowels (ya, yu, and yo), although there are few exceptions in case of Katakana. If learners fail to correctly identify the basic letters they feel frustrated and gradually lose their interest which in turn leads them to quit the course.

To resolve the difficulties of identifying letters different techniques were effectively used by different researchers. For example, Egeland (1975) used a procedure to teach pre-kindergarten children as to how to distinguish between the confusable letter pairs $R-P, Y-V, G-C, Q-$ $O, M-N$, and $K-X$. In deed, he used the procedure by which children can identify the distinctive feature (s) of a letter. An effective method for emphasizing a distinctive feature is initially to make it a different color from the rest of the pattern and gradually change it back to the original color. Employing this technique Egeland found that distinctive featuring results significantly fewer errors. Emphasizing the distinctive features produce two benefits. First, it enables the learner to learn the distinctive features so they can continue to differentiate letters after the distinctive features are no longer highlighted. Second, it enables the learner to learn features without making many errors during training session.

\subsection{Aim of the study}

It was observed that there is a high rate of drops-out among the students of Bangladesh in learning Japanese. Initially they were found to have high motivation. But as the course proceeds, their interests gradually declined. This could be due to their difficulty to correctly identify letters. This difficulty in turn may cause them read Japanese poorly. A few days later, their frustration grows and it rises to such a level that they think of quitting.. The aim of the present study was to investigate whether Katakana or Hiragana is difficult to learn. And in this respect to offer a cognitive psychological explanation of the difficulties of learning different scripts of Japanese.

\subsection{Hypothesis}

In relation to the aim of the study it was hypothesized that Katakana is difficult to learn than Hiragana.

\section{Method}

\subsection{Respondents}

A survey was carried out on 22 learners of Junior Certificate Course of Japanese in the Institute of Modern Languages at the University of Dhaka, Bangladesh. Among them 10 were male and others were female. The samples were collected on the basis of incidental sampling technique.

\subsection{Instruments}

A self-report instrument was constructed to collect data from the respondents. The instrument contained some basic demographical 
questions like name, gender, age etc. In addition to this a question was given to respond whether Katakana or Hiragana appears to be difficult to learn. They were instructed to give tick $(\sqrt{ })$ to the perceived difficult one. Scoring was completed by considering the difficult one as " 1 " and the other one as " 0 ".

\subsection{Procedure}

Standard data collection procedure was followed for the present investigation. The respondents were chosen incidentally from the IML during their free time. They were instructed to read the instruction attentively and give tick to the appropriate one. After collection of the data they were thanked for the participation.

\section{Findings}

Obtained data was compiled into a frequency table. From the frequency table it was found that 22 of the respondents indicated that Katakana seemed to be difficult to learn than Hiragana. As all the respondents indicated Katakana to be difficult than Hiragana, no inferential statistics were used to validate the current findings.

\section{Discussion}

The present paper was intended to determine whether Katakana or Hiragana is difficult to learn. For this purpose a survey was carried out over 22 respondents where all the respondents indicated that Katakana seemed to be difficult to learn for them. To support these findings we provide here two cognitive psychological explanations. Two possible explanations proposed were based on primacy effect theory and feature theory. Detailed explanations of these are given as follows.

In a free-recall experiment the likelihood of an individual item from a list being recalled is a function of the location of that item in the serial presentation of the list during learning. Items which are toward the beginning of the list and those toward the end are more likely to be correctly recalled than those in the middle (Reber, 1995). This phenomenon is called primacy effect in Cognitive Psychology. In Japanese course Hiragana is taught first followed by Katakana. It is, therefore, likely that owing to the primacy effect Hiragana is better learned. But as Katakana is taught later it is less recalled and hence shows difficulties in identifying.
This assumption can be tested in the laboratory with three groups of matched participants. The first group will be assigned to learn Hiragana first followed by Katakana. The second group will be just the opposite i.e., Katakana first followed by Hiragana. The final group will be allowed to learn both Hiragana and Katakana simultaneously. That is to say, the Katakana/Hiragana letter will be presented in pair with the corresponding Hiragana/Katakana letter. The complete design of the proposed experiment is shown in Table 1. By matched group is meant here that the participants of all groups will be completely novice with respect to learning Hiragana and Katakana. And also they will be equivalent with respect to their age, education, and sex. If, after the experiment is over, we find that Hiragana is better learned in the first group and Katakana in the second group whereas Hiragana and Katakana is significantly better learned respectively in the first and second groups than the third group then we can accept our hypothesis. We propose the other factors to be the distinctive features of Hiragana and Katakana.

\begin{tabular}{lll}
\multirow{2}{*}{ Proposed experimental design to test serial-position effect } \\
\cline { 2 - 3 } & Order of Learning \\
\hline 1 & Earlier & Later \\
2 & Hiragana & Katakana \\
3 & Katakana & Hiragana \\
\hline Table 1 & \multicolumn{2}{c}{ Hiragana + Katakana simultaneously } \\
\hline
\end{tabular}

Another very strong theoretical support can be drawn for the feature theory of perception. Generally, distinctive feature of an object or event is an attribute (s) that is critical in distinguishing that object or event from others. The term enjoys wide currency in psychology and related disciplines. In most psychological parlance it is used loosely to refer to attributes of persons, places, events or concepts that help to differentiate them from other persons, places, events or concepts. In identifying letters of any set of alphabet it is important to distinguish one letter from another. Distinctive features of letters help the learners to distinguish correctly the particular letter from other letters (Reber, 1995). 
According to feature model, information is stored in the form of a set of distinctive features that uniquely identify each concept. Feature theories allow us to describe patterns by listing the parts of a pattern. Feature theories are convenient for describing perceptual learning, and one of the best discussions of feature theories is contained in Gibson's Principles of Perceptual Learning and Development (Gibson, 1969). The theory proposes that perceptual learning occurs through the discovery of features that distinguish one pattern from another. Children learn to identify an object by being able to identify differences between it and other objects. For example, when first confronted with the letters $E$ and $F$, the child might not be aware of how the two differ. Learning to make this discrimination depends on discovering that the lowest horizontal line is present in the letter $E$ but not in the letter $F$. The lowest horizontal line is a distinctive feature for distinguishing between an $E$ and an $F$; that is, it enables us to distinguish one pattern from the other (Reed, 1996).

Difficulties in learning Katakana can best be explained by the feature model of Cognitive Psychology. Each letter of Hiragana and Katakana comprised of a set of strokes. Strokes are marks made by moving pen, brush etc. once across a surface. Strokes can be considered as features that distinguish one letter from another. Hence it can be said that the alphabet which comprised of more strokes have more distinctive features. And the alphabet which comprised of more distinctive features will be easier to learn. But the alphabet which comprised of fewer strokes has less distinctive features. Hence, the alphabet comprised of fewer distinctive features will be difficult to learn than the alphabet comprising more distinctive features.

To provide evidence for the assumption a careful investigation into the strokes of Hiragana and Katakana was carried out. It was found there are 58 strokes in Hiragana and 32 in Katakana. The number of strokes in Hiragana is almost double of the strokes in Katakana. This implies that Katakana having fewer strokes is less distinctive and hence more difficult to be learned. On the other hand, Hiragana, having more strokes is more distinctive and hence easier to be learned.
The Katakana alphabets can be taught employing the techniques of highlighting distinctive features of confusing letters. This will help the learners to identify the confusing letters without making many errors. And we all know that the failure in the early stage of learning leads to frustration. The frustration that many learners experience in the early stages of reading (letter discrimination) can result in the increase of loosing interest in later classroom learning.

The learners of Japanese should be highly motivated so that their frustration can not grow up to such level that leads them to quit the course. The learners should also practise writing Hiragana and Katakana more and more. It is important to keep in mind that learning any foreign language is never an easy task. It is even more important to note that learning language involves higher cognitive processes and is relatively challenging at the age of 20 or above. Finally, we suggest that future study is needed to examine potential hypotheses concerning difficulties in language learning.

\begin{tabular}{|c|c|c|c|c|c|c|c|c|c|c|}
\hline \multicolumn{11}{|c|}{ Strokes of Katakana } \\
\hline - & 1 & क & l & 1 & - & 7 & 7 & 2 & b & \\
\hline ) & 7 & $y$ & - & $<$ & $l$ & & $\rightarrow$ & 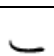 & L & - \\
\hline d & 了 & L & そ & l & 5 & 3 & $\tau$ & 1 & $<$ & $\alpha$ \\
\hline ね & 0 & $\alpha$ & U & $J$ & $r$ & د & ح & 2 & ) & $d$ \\
\hline U & $s$ & 1 & 0 & ) & $b$ & ) & 2 & $n$ & 3 & 々 \\
\hline$几$ & 2 & I & & & & & & & & \\
\hline
\end{tabular}

Table 2 


\begin{tabular}{|c|c|c|c|c|c|c|c|c|c|c|}
\hline \multicolumn{11}{|c|}{ Strokes of Katakana } \\
\hline$\rightarrow$ & J & ノ & I & 1 & 一 & l & - & 1 & - & 了 \\
\hline 7 & - & - & 1 & 7 & ) & $ノ$ & $\checkmark$ & L & ノ & 7 \\
\hline 1 & $ح$ & $\rightarrow$ & - & $L$ & $\neg$ & L & ) & 1 & 1 & \\
\hline
\end{tabular}

Table 3

The number of strokes in letters of Hiragana and corresponding Katakana with their sounds written in English

\begin{tabular}{|c|c|c|c|c|c|c|c|c|}
\hline $\begin{array}{l}\text { So } \\
\text { un } \\
\text { ds }\end{array}$ & $\begin{array}{c}\text { Hirag } \\
\text { ana }\end{array}$ & $\begin{array}{c}\text { Katak } \\
\text { ana }\end{array}$ & $\begin{array}{l}\text { So } \\
\text { un } \\
\text { ds }\end{array}$ & $\begin{array}{c}\text { Hirag } \\
\text { ana }\end{array}$ & $\begin{array}{l}\text { Kata } \\
\text { kana }\end{array}$ & $\begin{array}{l}\text { So } \\
\text { un } \\
\text { ds }\end{array}$ & $\begin{array}{l}\text { Hirag } \\
\text { ana }\end{array}$ & $\begin{array}{c}\text { Katakan } \\
\text { a }\end{array}$ \\
\hline $\mathrm{a}$ & $\begin{array}{l}\text { あ } \\
\text { (3) }\end{array}$ & $\begin{array}{l}P \\
(2)\end{array}$ & ta & $\begin{array}{l}\text { た } \\
(4)\end{array}$ & $\begin{array}{l}\text { 夕 } \\
(3)\end{array}$ & $\mathrm{ma}$ & ま (3) & $\checkmark(2)$ \\
\hline $\mathrm{i}$ & $\begin{array}{l}(1) \\
(2)\end{array}$ & $\begin{array}{l}1 \\
(2)\end{array}$ & $\begin{array}{c}\mathrm{ch} \\
\mathrm{i}\end{array}$ & $\begin{array}{l}5 \\
(2)\end{array}$ & $\begin{array}{l}\text { 千 } \\
(3)\end{array}$ & $\mathrm{mi}$ & み(2) & $\Xi(3)$ \\
\hline $\mathrm{u}$ & j) & $\begin{array}{l}\text { ウ } \\
\text { (4) }\end{array}$ & $\begin{array}{l}\mathrm{ts} \\
\mathrm{u}\end{array}$ & (1) & $\begin{array}{l}\because \\
(3)\end{array}$ & $\begin{array}{c}\mathrm{m} \\
\mathrm{u}\end{array}$ & む (3) & $\angle(2)$ \\
\hline e & $\begin{array}{l}\text { え } \\
(3)\end{array}$ & $\frac{I}{(3)}$ & te & $\begin{array}{c}\tau \\
(1)\end{array}$ & $\begin{array}{l}\text { テ } \\
(3)\end{array}$ & me & め (2) & メ (2) \\
\hline 0 & $\begin{array}{l}お \\
(3)\end{array}$ & $\begin{array}{l}\text { 才 } \\
(3)\end{array}$ & to & と & $\begin{array}{l}\text { 卜 } \\
(2)\end{array}$ & $\begin{array}{c}\mathrm{m} \\
\mathrm{o}\end{array}$ & 毛 (3) & E (3) \\
\hline ka & $\begin{array}{l}\text { か } \\
(3)\end{array}$ & $\begin{array}{l}\text { 力 } \\
(2)\end{array}$ & na & $\begin{array}{l}\text { な } \\
(4)\end{array}$ & $\begin{array}{l}\text { 十 } \\
(2)\end{array}$ & ya & や(3) & $ヤ_{(2)}$ \\
\hline ki & $\begin{array}{l}\text { (4) } \\
\text { (4) }\end{array}$ & $\begin{array}{l}\text { キ } \\
(3)\end{array}$ & ni & $\begin{array}{l}1= \\
\text { (3) }\end{array}$ & $\frac{}{(2)}$ & $\mathrm{yu}$ & ゆ(3) & 그 (2) \\
\hline $\mathrm{ku}$ & $\begin{array}{l}< \\
(1)\end{array}$ & $\begin{array}{l}7 \\
(2)\end{array}$ & $\mathrm{nu}$ & $\begin{array}{l}\not 2 \\
(2)\end{array}$ & $\begin{array}{l}\text { 又 } \\
(2)\end{array}$ & yo & L (2) & $\exists(4)$ \\
\hline ke & $\begin{array}{l}\text { if } \\
(3)\end{array}$ & $\begin{array}{l}\text { 广 } \\
\text { (3) }\end{array}$ & ne & $\begin{array}{l}\text { ね } \\
(2)\end{array}$ & $\begin{array}{l}\text { ネ } \\
(4)\end{array}$ & $\mathrm{ra}$ & $\grave{b}(2)$ & ラ (2) \\
\hline ko & $\frac{2}{(2)}$ & $\begin{array}{l}コ \\
(3)\end{array}$ & no & $\begin{array}{l}\text { ) } \\
(1)\end{array}$ & (1) & ri & $\eta(2)$ & I) (2) \\
\hline sa & $\begin{array}{l}x \\
(3)\end{array}$ & $\begin{array}{l}+ \\
(3)\end{array}$ & ha & $\begin{array}{l}\text { は } \\
(3)\end{array}$ & $\begin{array}{l}11 \\
(2)\end{array}$ & $\mathrm{ru}$ & る (1) & ル (2) \\
\hline
\end{tabular}

\begin{tabular}{|c|c|c|c|c|c|c|c|c|}
\hline $\begin{array}{c}\text { sh } \\
\text { i }\end{array}$ & $\underset{(1)}{L}$ & $\begin{array}{l}シ \\
\text { (3) }\end{array}$ & hi & $\bigcup_{(1)}$ & $\begin{array}{l}\text { 匕 } \\
(2)\end{array}$ & re & $れ_{(2)}$ & $L^{(1)}$ \\
\hline $\mathrm{su}$ & $\begin{array}{l}\text { f } \\
\text { (2) }\end{array}$ & $\begin{array}{c}\text { ス } \\
\text { (2) }\end{array}$ & fu & (4) & $\begin{array}{l}7 \\
\text { (1) }\end{array}$ & ro & 3 & $\square$ (4) \\
\hline se & せ & $\begin{array}{l}セ \\
(2)\end{array}$ & he & $\widehat{(1)}$ & $\widehat{(1)}$ & wa & わ (2) & 7 (3) \\
\hline \multirow[t]{2}{*}{ SO } & $\begin{array}{l}\text { そ } \\
\text { (1) }\end{array}$ & $\begin{array}{l}\text { (2) } \\
\text { (2) }\end{array}$ & ho & $\begin{array}{l}\text { l毛 } \\
\text { (4) }\end{array}$ & $\begin{array}{l}\text { ホ } \\
\text { (4) }\end{array}$ & wo & を(3) & $\exists$ (2) \\
\hline & & & & & & $\mathrm{n}$ & $h_{(1)}$ & ン (2) \\
\hline
\end{tabular}

Table 4

Note: Numbers in parentheses indicate the numbers of strokes require writing the corresponding letter

\section{References}

Egeland, B. 1975. Effects of errorless training on teaching children to discriminate letters of the alphabet. Journal of Applied Psychology, 60, 533-536.

Gibson, E. J. 1969. Principles of perceptual learning and development. Englewood Cliffs, N J: Prentice-Hall.

Reber, A. S. 1995. The Penguin Dictionary of Psychology, (2nd ed.). Canada: Penguin Books.

Reed, K. S. 1996. Cognition, Fourth Edition, Brooks/Cole Publishing Company, 2, 24-29.

Contact: shossain087@yahoo.com 